\title{
Fungsionalisasi Undang-Undang Darurat, Nomor 1 tahun 1951 sebagai Suplementasi dari Pasal 284 Kitab Undang-Undang Hukum Pidana Indonesia
}

\author{
Henni Muchtar*, Muhammad Prima Ersya \\ Fakultas Ilmu Sosial, Universitas Negeri Padang, Indonesia \\ Corresponding author's e-mail : hennimuchtar@gmail.com
}

\begin{tabular}{|c|c|}
\hline ARTICLE INFO & Abstract \\
\hline $\begin{array}{l}\text { Keywords: } \\
\text { Adultery; Emergency Law; } \\
\text { Fungsionalisasi } \\
\text { How To Cite: } \\
\text { Muchtar, H., E Ersya, M.P. (2019). } \\
\text { Fungsionalisasi Undang-Undang } \\
\text { Darurat, Nomor } 1 \text { tahun } 1951 \text { sebagai } \\
\text { Suplementasi dari Pasal } 284 \text { Kitab } \\
\text { Undang-Undang Hukum Pidana } \\
\text { Indonensia. Nagari Law Review, 3(1), } \\
\text { 78-88. } \\
\text { DOI: } \\
\text { 10.25077/nalrev.v.3.i.1.p.78-88.2019 }\end{array}$ & $\begin{array}{l}\text { The Penal Code of Indonesia as the heritage of Colonial Regime, in some instances } \\
\text { is not in line with the people of Indonesia. One of them is that the article } 284 \\
\text { concerning the prohibition of adultery, that has difference in concept with the } \\
\text { values owned by Indonesian people. Therefore, there should be a breakthrough } \\
\text { that the article adopts contemporary condition and be in line with the way of life } \\
\text { of the people of Indonesia, especially related the first pillar of Pancasila, that is } \\
\text { believe in one God. The purpose of this article is to discuss and convey the idea } \\
\text { of the existence of Emergency Law No. } 1 \text { of } 1951 \text { concerning Temporary } \\
\text { Measures in Organizing the Unity of the power and procedure of Civil Courts as } \\
\text { supplementation of the article } 284 \text { of the Penal Code. This research applied } \\
\text { normative juridical method and applicable law approach. The result of this study } \\
\text { finds that Article } 284 \text { of the Penal Code could basically be accepted as one of the } \\
\text { offense entities, but it is considered as lack Indonesia's spirit, even some consider } \\
\text { that it not as a form of values in Indonesia people. The compliance between the } \\
\text { law and the nation's spirit is very important because the nation's spirit is a } \\
\text { source of material law that creates people's legal awareness, as a guideline for law } \\
\text { enforcement, as well as a source of the people's law obidience. Considering the } \\
\text { weaknesses and limitations of the article } 284 \text { of Penal Code in regulating adultery } \\
\text { and the controversy of several articles in the draft Criminal Code which ended by } \\
\text { the suspension of enactment and implementation, the Emergency Law No. } 1 \text { of } \\
\text { 1951 can be enforced as supplementation of th article } 284 \text { of the Penal Code in } \\
\text { order to maintain the balance and order in the society. }\end{array}$ \\
\hline
\end{tabular}

(C2019 NALREV. Faculty of Law Universitas Andalas

\section{Pendahuluan}

Hukum merupakan gejala universal yang memiliki substansi yang berbeda-beda di setiap negara. Perbedaan hukum di setiap negara dipengaruhi oleh faktor jiwa bangsa suatu negara. Jiwa bangsa menjelma menjadi hukum yang tumbuh dan berkembang bersama-sama dengan tumbuh dan berkembangnya suatu bangsa. Menurut mazhab sosiologis, hukum merupakan salah satu gejala dari adanya masyarakat. Negara ditugasi untuk melembagakan hukum yang hidup (kebiasaan) di tengah-tengah masyarakat yang bersangkutan. Oleh karenanya, hukum yang berlaku di negara 
Indonesia memilik perbedaan corak dan warna dengan hukum yang berlaku di negara Belanda dan negara-negara lainnya.

Friedrich Carl Von Sovigny dalam bukunya yang terkenal “Von Beruf Unserer Zeit Fur Gesetz Gebung und Rechtswissenschaft", "Tentang Tugas Zaman Kita bagi Pembentuk Undang-Undang dan Ilmu Hukum", antara lain dikatakan : "Das Recht Wird nicht Gemacht, est ist und Wird Mit Dem Volke" (hukum itu tidak dibuat, akan tetapi tumbuh dan berkembang bersama masyarakat). Pandangan Von Savigny ini berpangkal kepada kenyataan bahwa di dunia ini terdapat bermacam-macam bangsa dan pada tiap-tiap bangsa tersebut mempunyai suatu Volkgeist (jiwa rakyat). Jiwa ini berbeda-beda, baik menurut waktu dan tempat. Tanda adanya suatu jiwa yang berbeda ini tampak pada kebudayaan dari bangsa tadi yang berbeda-beda. Hukum sangat bergantung atau bersumber pada jiwa rakyat tadi dan yang menjadi isi dari hukum itu ditentukan oleh pergaulan hidup manusia dari masa ke masa (sejarah)1. Karenanya, sangat tidak mungkin terdapat hukum yang berlaku universal dan sepanjang zaman. Oleh sebab itu, hukum timbul dan berkembang bukan hanya sekedar memenuhi atau melindungi kebutuhan manusia secara fisik, namun hukum sebagai pranata sosial juga harus akomodatif memenuhi atau melindungi kebutuhan jiwa manusia akan keadilan dan kedamaian, agar hukum menjadi efektif tegak dalam masyarakat.

Dalam kajian filsafat hukum yang terkait dengan tujuan hukum, Gustav Radbruch, seorang filsuf hukum berkebangsaan Jerman, memberikan pendapatnya yang terkenal terkait tujuan hukum. Radbrug menyampaikan bahwa ada tiga ide dasar tujuan hukum (idee des recht), yaitu keadilan (gerechtigkeit), kemanfaatan (zweckmaeszigkeit), dan kepastian hukum (rechtssicherkeit). ${ }^{2}$ Bila dijabarkan lebih lanjut, asas kepastian hukum meninjau hukum dari sudut yuridis, asas keadilan hukum meninjau hukum dari segi filosofis dan asas kemanfaatan hukum meninjau hukum dari aspek sosiologis. Tujuan hukum yang disampaikan Radbrug merupakan tujuan hukum yang linear dengan konsep hukum progresif yang diusung Satjipto Rahardjo, dengan prinsip utama bahwa hukum adalah untuk manusia, dan bukan sebaliknya. ${ }^{3}$

Dalam membangun hukum yang ideal sebenarnya sudah dapat dilakukan oleh bangsa Indonesia sejak Proklamasi Kemerdekaan Indonesia tahun 1945. Selain memiliki makna sebagai puncak dari perjuangan bangsa yang tiada lelah, proklamasi seyogyanya juga dapat diartikan sebagai momentum berakhirnya sistem atau tata hukum dan pemerintahan penjajah di Indonesia dan dimulainya sistem atau tata hukum dan pemerintahan negara Indonesia merdeka. Sebab itulah bangsa Indonesia memiliki kesempatan yang leluasa untuk menentukan hukum sendiri yang mandiri serta responsif. Namun, pada kenyataannya sampai sekarang ini masih banyak aturan pokok atau induk Indonesia yang merupakan warisan (legacy) dari penjajah dahulu, salah satunya adalah Wetboek van Strafrecht ${ }^{4}$ atau Kitab Undang-Undang Hukum Pidana (KUHP), dengan dasar pemberlakuannya sampai hari ini adalah Pasal 1 Aturan Peralihan Undang-Undang Dasar Negara Republik Indonesia Tahun 1945 (UUD 1945) dan Peraturan Pemerintah Nomor 2 Tahun 1945 tentang Badan-Badan dan Peraturan

${ }^{1}$ H. Mustaghfirin. (2011). Sistem Hukum Barat, Sistem Hukum Adat, dan Sistem Hukum Islam Menuju sebagai Sistem Hukum Nasional Sebuah Ide yang Harmoni. Jurnal Dinamika Hukum. Vol. 11 Edisi Khusus Februari 2011, Fakultas Hukum, Universitas Jenderal Soedirman, hlm. 94.

2 Achmad Ali. 2002. Menyibak Tabir Hukum, Gunung Agung, Jakarta, hlm. 3.

3 I Gede Wiranata. 2006. Membedah Hukum Progresif. Kompas Media Nusantara. Jakarta: hlm. 114.

4 Berdasarkan Undang-Undang Nomor 1 Tahun 1946, Pasal 6 ayat (1), nama undang-undang hukum pidana "Wetboek van Strafrecht voor Nederlandsch-Indie" dirubah menjadi "Wetboek van Strafrecht" dan selanjutnya undang-undang tersebut dapat disebut dengan Kitab Undang-Undang Hukum Pidana (vide Pasal 6 ayat(2)). 
Pemerintah dulu. Walaupun telah dilakukan beberapa kali pemurnian (purification) dan perubahan, diantaranya melalui Undang-Undang Nomor 1 Tahun 1946 tentang Peraturan Hukum Pidana, Undang-Undang Nomor 1 Tahun 1960 tentang Perubahan Kitab Undang-Undang Hukum Pidana dan Undang-Undang Nomor 4 Tahun 1976 tentang Perubahan dan Penambahan Beberapa Pasal dalam Kitab Undang-Undang Hukum Pidana Bertalian dengan Perluasan Berlakunya Ketentuan Perundang-undangan Pidana, Kejahatan Penerbangan, dan Kejahatan Terhadap Sarana/Prasarana Penerbangan dan Undang-Undang Nomor 27 Tahun 1999 tentang Perubahan Kitab Undang-Undang Hukum Pidana yang Berkaitan dengan Kejahatan terhadap Keamanan Negara. Serta telah dilakukan juga unifikasi hukum pidana di Indonesia dengan Undang-Undang Nomor 73 Tahun 1958 tentang Menyatakan Berlakunya Undang-Undang Nomor 1 Tahun 1946 Republik Indonesia tentang Peraturan Hukum Pidana untuk Seluruh Wilayah Republik Indonesia dan Mengubah UndangUndang Hukum Pidana. Sampai saat ini, baik pemurnian maupun perubahan KUHP secara parsial tersebut belum mampu memenuhi kebutuhan hukum bangsa Indonesia, bahkan menimbulkan permasalahan baru. Dikarenakan adanya perbedaan yang signifikan antara jiwa atau rohani bangsa, antara bangsa Belanda dengan bangsa Indonesia, juga disebabkan Wetboek van Strafrecht tidak memiliki terjemahan resmi yang disahkan oleh badan berwenang tertentu ke dalam bahasa Indonesia, sehingga sulit untuk menyatukan persepsi baik dalam masa pendidikan hukum maupun dalam praktiknya.

Kajian-kajian hukum dalam konteks konsep, Das Sollen (law in the books), untuk memperbaiki praktik hukum konkrit, Das Sein (law in actions), dari para sarjana hukum, menuntut adanya solusi alternatif untuk mensuplementasi Pasal 284 KUHP yang dirasakan telah "usang" secara materi muatan (unsurunsur), karena jangkauannya yang tidak kekinian untuk menjerat para pelaku zina dari orang-orang yang tidak terikat perkawinan yang sah. Kajian-kajian tersebut muncul berdasarkan aksioma bahwa zina dan "kumpul kebo" merupakan suatu problematik tersendiri dalam konteks kehidupan masyarakat Indonesia, baik yang hidup di kota (modern) maupun di desa secara tradisional. Dan, telah banyak studi yang menunjukan bahwa zina menjadi salah satu faktor resiko yang dapat menimbulkan kerusakan beragama, penderitaan psikis dan gangguan kesehatan para pelakunya dan dampaknya juga dapat meluas sebagai faktor penyebab kerusakan tatanan kehidupan sosial masyarakat. Sebagai akibatnya, zina menimbulkan kecemasan khususnya bagi orang tua dan suami atau isteri dalam perkawinan yang sah.

Berdasarkan Survey Demografi dan Kesehatan Indonesia (SDKI) tahun 2017, mengungkap sekitar 2 persen remaja wanita usia 15-24 tahun dan 8 persen remaja pria di rentang usia yang sama, telah melakukan hubungan seksual sebelum menikah. Menurut Tin Afifah, SKM., MKM, seorang peneliti dari Badan Penelitian dan Pengembangan Kesehatan (Balitbangkes) Kementerian Kesehatan, jumlah ini adalah yang tercatat dan yang tidak terdata menurutnya bisa jadi lebih banyak ${ }^{5}$. Sebelumnya, Badan Koordinasi Keluarga Berencana di tahun 2008 pernah mengumumkan hasil surveinya, bahwa 63 persen remaja SMP dan SMA di Indonesia pernah berhubungan seks. Sebanyak 21 persen diantaranya melakukan aborsi ${ }^{6}$. Dan, dari data situs www.go-dok.com, yang kemudian dikutip

5 https://health.detik.com/berita-detikhealth/d-4249233/gunung-es-perilaku-seks-pranikah-di-kalanganremaja.

Diposting pada Selasa, 09 Oktober 2018 pukul 18:28 WIB, diunduh pada Kamis, 22 November 2018 pukul 02:12 WIB.

${ }^{6}$ http:/ / wahdah.or.id/bkkbn-63-remaja-indonesia-ngeseks-pra-nikah/. Diposting pada 20 Desember 2008. diunduh pada Kamis, 22 November 2018 pukul 03:08 WIB. 
dalam artikel berita online www.kumparan.com, menyatakan bahwa 68 persen remaja Indonesia rentan perilaku seks bebas7 ${ }^{7}$ Selanjutnya, Ketua Presidium Indonesian Police Watch (IPW) Neta S. Pane mengungkapkan, tingkat sadisme dan seks bebas di kalangan remaja Indonesia kian memprihatinkan, ditandai makin tingginya angka pembuangan bayi di jalanan di sepanjang Januari 2018. IPW mendata sepanjang Januari 2018 bayi yang dibuang di Indonesia ada sebanyak 54 bayi. Angka ini mengalami kenaikan dua kali lipat (100 persen lebih) jika dibandingkan dalam periode yang sama pada Januari 2017, yang hanya ada 26 kasus pembuangan bayi. ${ }^{8}$

Pada tahun 2016, Prof. Euis Sunarti, seorang guru besar di bidang ketahanan dan pemberdayaan keluarga Institut Pertanian Bogor bersama sebelas orang lainnya dengan latar belakang yang berbeda, mengajukan permohonan uji materiil terhadap Pasal 284, 285 dan 292 KUHP dengan nomor perkara : 46/PUU-XIV/2016 kepada Mahkamah Konstitusi dan telah diputus oleh majelis hakim konstitusi pada tanggal 14 Desember 2017. Para pemohon merupakan presentasi dari setiap orang yang memiliki kekhawatiran terhadap kurang efektifnya pasal perzinahan (ovespel) yang ada sekarang ini. Kekhawatiran ini juga sejalan dengan fakta data yang menunjukan banyaknya saat ini pelaku perzinahan di Indonesia yang dilakukan oleh generasi muda/remaja khususnya dengan berbagai dampak negatif yang ditimbulkannya. Oleh sebab itu, para pemohon uji materiil tersebut berharap agar Mahkamah Konstitusi dapat memberikan solusi alternatif, percepatan dan kepastian hukum, sementara dilakukannya legislative review KUHP, khususnya terkait Pasal 284 KUHP yang sudah usang dan uzur.

Dengan semangat yang sama, Prof. Oemar Senoadji mengemukakan bahwa penentuan isi (materi/substansi) delik kesusilaan harus bersumber dan mendapat sandaran kuat dari moral agama. Penentuan delik kesusilaan juga harus berorientasi pada "nilai-nilai kesusilaan nasional" yang sudah disepakati bersama dan juga memperhatikan nilai-nilai kesusilaan yang hidup di dalam masyarakat. Nilai-Nilai tersebt ini dapat digali antara lain dari produk legislatif nasional (berbentuk UUD atau UU). Dalam struktur masyarakat Indonesia, nilai-nilai kesusilaan nasional itu pun bersumber dari nilai-nilai agama dan kesusilaan yang hidup di tengah-tengah masyarakat. ${ }^{9}$ Sehingga terwujud hukum yang efisien dalam hal perumusannya dan efektif dalam hal penerapannya.

Penulis melakukan penelitian ini dengan mencari unsur-unsur objektif dalam unsur-unsur subjektif terkait urgensi mereposisi unsur-unsur melawan hukum dalam Pasal 284 KUHP agar dapat bersifat kontemporer baik secara materiil maupun formal sesuai dengan jiwa bangsa Indonesia pada umumnya dan cocok dengan makna implisit Sila Pertama Pancasila, Ketuhanan Yang Maha Esa.

7 https:/ / kumparan.com/go-dok-indonesia/ data-go-dok-68-remaja-indonesia-rentan-perilaku-seks-bebas.

Diposting pada 29 Agustus 2017 pukul 10:07 WIB, diunduh pada Kamis, 22 November 2018 pukul 03:08 WIB.

${ }^{8}$ https://www.eramuslim.com/berita/nasional/pergaulan-bebas-di-kalangan-remaja-indonesia-kian2018

mencemaskan.htm\#.W_XBv4czbIV. Diposting pada 1 Februari 2018, diunduh pada Kamis, 22 November

pukul 03:08 WIB.

9 Barda Nawawi Arief. (2014). Bunga Rampai Kebijakan Hukum Pidana, Perkembangan Penyusunan Konsep KUHP Baru, Jakarta: Kencana Pradana Medmia Group, hlm. 251. Terdapat juga dalam Salinan Putusan Mahkamah Konstitusi nomor 46/PUU-XIV/2016, hlm. 27. 


\section{Metode}

Embahasan permasalahan ini digunakan metode penelitian yuridis normatif dengan pendekatan terhadap hukum yang berlaku. Pengkajiannya dapat digolongkan sebagai penelitian normatifdoktrinal dengan pendekatan konseptual (conseptual approach). Melalui pendekatan konseptual, penulis akan merujuk pada prinsip-prinsip, asas-asas, dan teori-teori hukum yang dikaitkan dengan pandangan sarjana atau doktrin-doktrin hukum. Kemudian dianalisis dengan metode analisis kritis (critical analysis) melalui pendekatan analisis komprehensif (comprehensive analysis). ${ }^{10}$ Tipe penelitian ini bersifat eksploratif yaitu suatu penelitian yang dilakukan untuk memperdalam pengetahuan mengenai suatu gejala tertentu atau untuk mendapatkan ide-ide baru mengenai suatu gejala tertentu tersebut ${ }^{11}$.

\section{Hasil dan Pembahasan}

Hukum Pidana ${ }^{12}$ harus senantiasa direorientasi dan direformasi dengan berbagai pendekatan agar sesuai dengan nilai-nilai sosial dan politik bangsa Indonesia, sehingga perannya dalam rangka menjaga dan melindungi dan menciptakan kesejahteraan masyarakat (social defence dan social welfare), khususnya sebagai pengendali kejahatan dapat diwujudkan ${ }^{13}$. Disambung oleh Eman Sulaeman, hukum yang baik dapat diberlakukan dengan efektif dan hukum yang baik selalu menuntut persyaratan secara yuridis, sosiologis, filosofis dan historis. Artinya, secara yuridis hukum itu sah, harus juga keberlakuannya didukung masyarakat, dan sesuai dengan nilai-nilai serta cita-cita hidup masyarakat yang bersangkutan, juga memiliki relevansi dengan tradisi hukum masyarakat itu sendiri ${ }^{14}$.

Dewasa ini masalah hukum pidana banyak dibicarakan dan menjadi sorotan, baik dalam teori maupun dalam praktek dan bahkan ada usaha untuk menyusun Kitab Undang-Undang Hukum Pidana Nasional. Usaha tersebut bertujuan untuk mengatasi pelbagai kelemahan dan kekurangan yang ada dalam KUHP yang berlaku sekarang, yang merupakan peninggalan zaman penjajahan yang dalam kenyataannya masih dipakai, yang ternyata banyak pengaturan di dalamnya yang sudah tidak sesuai lagi dengan jiwa dan semangat pancasila dan UUD 1945 maupun dengan situasi dan kondisi masyarakat saat ini ${ }^{15}$. Sehingga, pada saat masyarakat Indonesia masih diikat dengan beragam peraturan yang sudah tidak sesuai lagi dengan nilai-nilai dasarnya, maka harapan untuk mendapatkan hukum yang baik tentu akan sangat jauh dari harapan.

Sebenarnya upaya untuk mereformasi hukum pidana nasional telah dilakukan semenjak tahun 1964, dimana tim penyusun konsep pertama buku I KUHP yang baru di tahun 1964 menyatakan dalam

${ }^{10}$ Soerjono Soekanto. (1986). Pengantar Penelitian Hukum, Cetakan Ketiga, Jakarta: UI-Press, hlm. 6.

${ }^{11}$ Bambang Sunggono, 2003, Metodologi Penelitian Hukum, Cetakan Kelima, Jakarta: Rajawali Pers, hlm. 25.

12 Menurut P. A. F. Lamintang, Norma hukum pidana lahir bila terjadi tindakan yang dipandang mendatangkan kerugian bagi kepentingan masyarakat. Dengan terganggunya kepentingan bersama, diperlukan suatu norma untuk penanggulannya dengan norma hukum pidana. Dengan itu diharapkan dapat melindungi kepentingan bersama berupa pemberian sanksi terhadap pelanggarnya. Lihat. Yoserwan., (2017) Penerapan Fungsi Sekunder Hukum Pidana Oleh Aparatur Penegak Hukum Dalam Hukum Pidana Ekonomi. Jurnal Nagari Law Review. Volume 1 Nomor 1, Oktober 2017, hlm. 17.

${ }^{13}$ Eman Sulaeman, 2008, Delik Perzinaan, Semarang : Walisongo Pers, hlm. 22.

14 Ibid., hlm. 24.

${ }^{15}$ Suparni Niniek. (2007). Eksistensi Pidana Denda dalam Sistem Pidana dan Pemidanaan, Jakarta: Sinar Grafika, hlm. 1. 
penjelasan umumnya bahwa walaupun UU No. 1 Tahun 1946 telah berusaha untuk disesuaikan dengan suasana kemerdekaan, namun pada hakikatnya asas-asas dan dasar-dasar tata hukum pidana masih tetap dilandaskan pada ilmu hukum pidana dan praktek hukum pidana kolonial ${ }^{16}$.

Barda Nawawi Arief ${ }^{17}$, menjelaskan latar belakang perlunya untuk merevisi KUHP, sebagai berikut :

1. KUHP dipandang tidak lengkap atau tidak dapat menampung berbagai masalah dan dimensi perkembangan bentuk-bentuk tindak pidana baru,

2. Kurang sesuai dengan nilai-nilai sosio-filosofis, sosio-politik dan sosio-kultural yang hidup dalam masyarakat,

3. Kurang sesuai dengan perkembangan pemikiran/ide dan aspirasi tuntutan/kebutuhan masyarakat (nasional/internasional),

4. Tidak merupakan sistem hukum pidana yang utuh, karena ada pasal/delik-delik yang dicabut.

Menurut Soerjono Soekanto ${ }^{18}$, bahwa efektif atau tidaknya suatu hukum ditentukan oleh 5 (lima) faktor, yaitu : 1. Faktor hukumnya sendiri, 2. Faktor penegak hukum, 3. Faktor sarana atau fasilitas yang mendukung penegakan hukum, 4. Faktor masyarakat, 5. Faktor kebudayaan. Jika dibaca dengan urutan prioritas, faktor hukum menempati prioritas pertama sebagai faktor efektifnya atau berhasil gunanya suatu hukum. Selanjutnya, Soerjono Soekanto menjelaskan terkait faktor hukum, bahwa dalam melihat hukum tidaklah semata-mata dilihat dari sudut hukum tertulis saja, masih banyak aturan-aturan yang hidup dalam masyarakat yang mampu mengatur kehidupan masyarakat. Bahkan, Soerjono Soekanto ${ }^{19}$ menegaskan bahwa hukum yang baik adalah hukum yang hidup dalam masyarakat. Hal ini didasarkan pada pendapat bahwa untuk mewujudkan nilai-nilai sosial yang dicita-citakan oleh masyarakat diperlukan kaidah hukum sebagai alatnya.

Hukum merupakan abstraksi dari suatu konsepsi-konsepsi nilai yang bersifat status quo di dalam masyarakat, seperti nilai keadilan. Menurut Paul Bohannan ${ }^{20}$, hukum merupakan aturan-aturan atau kebiasaan yang telah mengalami proses pelembagaan kembali (reinstitutionalization of norms). Secara sosiologis, hukum merupakan lembaga kemasyarakatan (social institution) yang merupakan himpunan nilai-nilai, kaidah-kaidah dan pola-pola perikelakuan yang berkisar pada kebutuhankebutuhan pokok manusia. ${ }^{21}$ Sehingga sebagai resultannya terbentuk suatu siklus ideal yang berupa kristalisasi dari ide-ide dan nilai-nilai hidup masyarakat yang berbentuk norma tidak tertulis yang kemudian dikristalisasikan menjadi hukum (norma tertulis) dan selanjutnya diinternalisasikan kembali untuk diaktualisasikan dalam kehidupan sehari-hari masyarakat yang taat hukum.

Apabila pembahasan di atas dijadikan sebagai pisau analisis dan dikaitkan dengan modernisasi Pasal 284 KUHP, maka untuk konteks masyarakat Indonesia yang beragama dengan falsafah negara Pancasila yang berdasarkan Ketuhanan Yang Maha Esa, menurut hemat penulis, keterlambatan dan regresifitas dalam merevisi unsur norma Pasal 284 KUHP tersebut mesti diakhiri. Sebagaimana yang

16 Barda Nawawi Arief, 2009, RUU KUHP Sebuah Restrukturisasi/Rekonstruksi Sistem Hukum Pidana Indonesia, Semarang: Badan Penerbit Universitas Diponegoro, hlm. 6.

17 Ibid. hlm. 17.

18 Soerjono Soekanto. (2008). Faktor-Faktor yang Mempengaruhi Penegakan Hukum, Jakarta: PT. Raja Grafindo Persada, hlm. 8 .

19 Soerjono Soekanto. (2013). Pokok-Pokok Sosiologi Hukum, Jakarta: PT. Raja Grafindo Persada, hlm. 17.

20 Ibid., hlm. 73. Kihat juga: Soerjono Soekanto dalam Paul Bohannan, "The Differing Realms of the Law.

Laura Nader (de). The Ethnography of Law, American Anthropologist, Part 2, Vol. 2, Number 6, December 1965.

21 Ibid., hlm. 4. 
disampaikan oleh Leopold Pospisil22 terkait empat hal yang menjadi dasar-dasar hukum, salah satu diantaranya attribute of intention of universal application, yakni hukum merupakan suatu keputusankeputusan yang mempunyai daya jangkau yang panjang untuk masa-masa datang. Sekurangkurangnya mencarikan suplementasi norma formalnya. Ini merupakan suatu refleksi untuk memahami bahwa hukum merupakan sebagai sebuah gejala kemasyarakatan dan sebagai suatu proses untuk mencapai ketentraman bersama.

Sebagaimana hukum yang tertulis (lex scripta; lex certa), aturan-aturan yang tidak tertulis pun dapat mengalami perubahan, bahkan perubahannya dapat lebih cepat daripada perubahan hukum yang tertulis. Kemampuan untuk selalu memoderasi hukum yang hidup agar sinkron dengan jiwa masyarakat merupakan suatu keniscayaan untuk mendapatkan penghayatan hukum yang lebih baik. Jika mengutip pendapat Prof. A. Suriyaman Mustari Pide23, maka akan dipahami bahwa kesadaran hukum dalam masyarakat baik secara individual maupun kolektif memiliki indikator dengan tahapan-tahapan sistematis sebagai berikut :

a. Pengetahuan hukum (law awareness), yakni tingkat pengetahuan (kognisi) seseorang mengenai beberapa perilaku tertentu yang diatur oleh hukum.

b. Pemahaman hukum (law acquaintance) adalah pengertian seseorang terhadap materi dan tujuan dari suatu peraturan dan manfaatnya bagi subjek-subjek yang terkena oleh peraturan tersebut.

c. Sikap hukum (legal attitude) merupakan penghargaan (respektivitas) terhadap hukum yang memiliki kecenderungan untuk menerima hukum yang bersangkutan sehingga mudah pula ditaati.

d. Pola perilaku hukum (legal behaviour), yaitu tindakan-tindakan yang dikehendaki oleh hukum.

Dengan kata lain, bahwa kesadaran hukum masyarakat berbanding lurus dengan nilai-nilai yang berlaku pada dimensi ruang dan dimensi waktu, sehingga nilai tersebut dapat menebal atau menipis pada saat yang lain karena kesepakatan masyarakat itu sendiri24. Infiltrasi jiwa bangsa ke dalam sebuah aturan hukum akan berakibat kepada sikap hukum masyarakat yang sesuai dengan hukum, dikarenakan pemahaman hukum masyarakat lebih dahulu muncul sebelum diformatkan ke dalam aturan formal. Jika pengetahuan hukum merupakan suatu ilmu atau materi hukumnya, maka bagaimana cara mengimplementasikannya, itulah yang dimaksud dengan pemahaman hukum.

Pasal $284 \mathrm{KUHP}$, secara umum, unsur-unsur perbuatan melawan hukumnya dapat diterima oleh masyarakat Indonesia sebagai entitas delict, baik secara formal maupun materiil, akan tetapi unsurunsur Pasal 284 KUHP tersebut juga dapat dirasakan kekurangan "cita rasa" jiwa bangsa Indonesia. Dimana jiwa bangsa ini adalah sumber hukum materiil yang menciptakan kesadaran hukum masyarakat dan sebagai pedoman penegakan hukum dan ketaatan hukum masyarakat.

Pengenyampingan jiwa bangsa tentu memiliki dampak negatif. Jika aturan hukum yang bersangkutan hanya diakui secara klasifikasi perbuatan melawan hukum formal saja serta tindak pidananya pun dirumuskan dengan perbuatan aktif (commission), maka permasalahan baru akan muncul. Misalnya, bisa saja pada kebanyakan orang awan, baru mengetahui adanya hukum setelah terjadi pelanggaran hukum yang dilakukan sendiri oleh yang bersangkutan. Hal ini akibat

22 Ibid., hlm. 75.

23 A. Suriyaman Mustari Pide. (2017). Hukum Adat : Dahulu, Kini dan Akan Datang, Jakarta; Prenada Media Grup, , hlm. 164.

${ }_{24}$ Ibid., hlm. 165. 
"pemaksaan" berhukum kepada norma-norma yang diambil dari nilai-nilai yang tidak dinisbahkan kepada jiwa bangsa secara konsekuen.

Dalam konstelasi sistem hukum Indonesia, terdapat solusi sementara ${ }^{25}$ yang dapat dipakai untuk memenuhi rasa keadilan masyarakat Indonesia yang telah merdeka. Berdasarkan Undang-Undang Darurat Nomor 1 Tahun 1951 tentang Tindakan-Tindakan Sementara untuk Menyelenggarakan Kesatuan Susunan Kekuasaan dan Acara Pengadilan-Pengadilan Sipil, dalam Pasal 5 ayat (3) huruf b, disebutkan bahwa "suatu perbuatan yang menurut hukum yang hidup harus dianggap perbuatan pidana, akan tetapi tiada bandingnya dalam Kitab Hukum Pidana Sipil, maka dianggap diancam dengan hukuman yang tidak lebih dari tiga bulan penjara dan/atau denda lima ratus rupiah..."

Frasa "menurut hukum yang hidup" dapat diterjemahkan sebagai hukum adat (kebiasaan, kursif penulis) masyarakat setempat, dimana locus delicti terjadi. Dalam konstruksi hukum Indonesia, hukum adat merupakan hukum asli bangsa Indonesia. Eksistensinya secara eksplisit ditemui pada Pasal 18B ayat (2) UUD 1945, dimana "negara mengakui dan menghormati kesatuan-kesatuan masyarakat hukum adat beserta hak-hak tradisionalnya sepanjang masih hidup..." Penghargaan kepada hukum asli yang didasarkan kepada jiwa bangsa Indonesia ini pun diberikan oleh UndangUndang Dasar sebelumnya. Pasal 146 ayat (1) Konstitusi RIS, menyatakan "segala keputusan kehakiman harus berisi alasan-alasannya dan dalam perkara hukuman harus menyebut aturanaturan perundangan dan aturan-aturan hukum adat yang dijadikan dasar hukuman tersebut". Sementara itu, di Pasal 104 ayat (1) UUDS 1950, dinyatakan bahwa "segala keputusan pengadilan harus berisi alasan-alasan dan dalam hukuman menyebut aturan-aturan dan aturan-aturan hukum adat yang dijadikan dasar hukum itu". Selanjutnya, Undang-Undang Nomor 48 Tahun 2009 tentang Kekuasaan Kehakiman, di Pasal 5 ayat (1) menyatakan bahwa "seorang hakim dan hakim konstitusi wajib menggali, mengikuti, dan memahami nilai-nilai hukum dan rasa keadilan yang hidup dalam masyarakat", di Pasal 50 ayat (1) menambahkan, bahwa pengadilan selain harus memuat alasan dan dasar putusan, juga memuat pasal tertentu dari peraturan perundang-undangan bersangkutan atau sumber hukum tak tertulis yang dijadikan dasar untuk mengadili. Dari redaksional frasa "atau" yang terdapat di Pasal 50 ayat (1), memiliki makna bahwa hakim memiliki solusi alternatif, apabila sumber keadilan masyarakat tidak terdapat dalam peraturan perundang-undangan, maka secara imperatif hakim terikat dengan hukum yang tidak tertulis yang hidup di tengah-tengah masyarakat. Selain itu, dalam Undang-Undang Nomor 6 tahun 2014 tentang Desa, Pasal 103 huruf (d), dijelaskan bahwa hukum adat memiliki hak untuk didahulukan (privilege) dalam hal penyelesaian sengketa adat. Selanjutnya, konsolidasi hukum adat dengan hukum nasional juga bisa ditemukan dalam UndangUndang Nomor 5 tahun 1960 tentang Peraturan Dasar Pokok-Pokok Agraria, Pasal 5 menyebutkan hukum agraria yang berlaku atas bumi, air dan ruang angkasa ialah hukum adat. Yang kemudian dipertegas dalam bagian Penjelasan Umum undang-undang tersebut, jika hukum agraria harus sesuai dengan kesadaran hukum daripada rakyat banyak. Oleh karena rakyat Indonesia sebagian besar tunduk pada hukum adat, maka hukum agraria yang baru tersebut akan didasarkan pula pada ketentuan-ketentuan hukum adat itu, sebagai hukum yang asli.

${ }^{25}$ Solusi sementara ini berdasarkan ketentuan Aturan Peralihan ayat (2) UUD 1945, bunyinya : "Segala badan negara dan peraturan yang ada masih langsung berlaku, selama belum diadakan yang baru menurut Undang-Undang Dasar ini". Yang kemudian diamandemen pada tahun 2002 menjadi Aturan Peralihan Pasal (1), yang bunyinya : "Segala peraturan perundang-undangan yang ada masih tetap berlaku selama belum diadakan yang baru menurut Undang-Undang Dasar ini". 
Di zaman sebelum kemerdekaan Indonesia, Belanda telah mengetahui dan mengakui kalau bangsa Indonesia telah memiliki hukum adat, baik yang diresepsi dari agama maupun jiwa bangsa. Politik hukum Belanda pada saat itu, berdasarkan Pasal 131 Indische Staatsregeling (IS) dan Pasal 163 IS, menggolongkan penduduk Hindia Belanda menjadi tiga golongan dan untuk golongan bumi putra, berlaku hukum adat bagi mereka atau dapat menundukan diri kepada sebagian maupun seluruhnya hukum Belanda secara concordantie. Selain itu, ahli dari Belanda yang bernama Christiaan Snouck Hurgronje ${ }^{26}$ dan Cornelis van Vallenhoven ${ }^{27}$ menuliskan hal-hal yang terkait dengan hukum adat di nusantara. Sebab itu, upaya dekolonialisasi seluruh aturan hukum Indonesia wajib dilakukan dengan menempuh langkah mengharmonisasikan setiap aturan formal negara dengan jiwa bangsa Indonesia yang merdeka.

Dalam Rancangan KUHP tahun 2017, di Bab XVI tentang Tindak Pidana Kesusilaan, Bagian keempat, Pasal 484 ayat (1) telah memasukan unsur-unsur perbuatan melawan hukum yang lebih komprehensif yang selama ini tidak terdapat dalam Pasal 284 KUHP. Selain itu, rancangan KUHP tersebut juga terlihat sangat menjiwai karakter bangsa Indonesia. Pasal 484 Rancangan KUHP tersebut berbunyi sebagai berikut :

Ayat (1) Dipidana karena zina, dengan pidana penjara paling lama 5 (lima) tahun :

a. laki-laki yang berada dalam ikatan perkawinan melakukan persetubuhan dengan perempuan yang bukan istrinya.

b. perempuan yang berada dalam ikatan perkawinan melakukan persetubuhan dengan laki-laki yang bukan suaminya.

c. laki-laki yang tidak dalam ikatan perkawinan melakukan persetubuhan dengan perempuan, padahal diketahui bahwa perempuan tersebut berada dalam ikatan perkawinan.

d. perempuan yang tidak dalam ikatan perkawinan melakukan persetubuhan dengan laki-laki, padahal diketahui bahwa laki-laki tersebut berada dalam ikatan perkawinan.

e. laki-laki dan perempuan yang masing-masing tidak terikat dalam perkawinan yang sah melakukan persetubuhan.

Delik zina dalam rancangan KUHP sangat terlihat progresif, dimana telah mengharmonisasikan dengan falsafah negara Indonesia Pancasila dan dasar negara Ketuhanan Yang Maha Esa. Namun, solusi atas kekosongan hukum selama ini, akibat unsur-unsur perbuatan melawan hukum yang terdapat dalam Pasal 284 KUHP yang tidak cukup representatif dalam mewakili rasa keadilan masyarakat, terasa terlalu lama untuk disahkannya. Oleh karenanya, masih relevan kiranya solusi suplementasi dengan menggunakan aturan "antik" yang terdapat dalam Undang-Undang Darurat Nomor 1 Tahun 1951 tentang Tindakan-Tindakan Sementara untuk Menyelenggarakan Kesatuan Susunan Kekuasaan dan Acara Pengadilan-Pengadilan Sipil dipakai untuk menjaga keseimbangan dan ketentraman dalam masyarakat.

26 Menurut literatur yang beredar secara populer di Indonesia, istilah hukum adat pertama kali dipopulerkan dengan sebutan adat recht dalam bukunya yang berjudul De Atjeher, yang diterbitkan dalam dua jilid pada tahun 1893 dan 1894.

${ }_{27}$ Nomenklatur adat recht juga dipakai oleh Cornelis van Vallenhoven dalam bukunya yang berjudul Het Adatrecht van Nederlandsch-Indie tahun 1933. Adat recht dipakai sebagai presentasi sistem hukum asli masyarakat Hindia Belanda (sebutan Indonesia pada masa kolonial Belanda) yang sesuai dengan jiwa bangsa Indonesia. 


\section{Penutup}

\subsection{Kesimpulan}

Setiap aturan hukum yang memoderasi jiwa suatu bangsa, setidak-tidaknya dapat memberikan garansi terhadap efektifitas hukum yang bersangkutan. Jiwa bangsa yang merupakan identitas kepribadian asli suatu bangsa, yang perlu dipelihara dengan cara memasukan nilai-nilainya ke dalam hukum nasional secara formal dalam upaya mendekolonialisasi hukum penjajah dahulu.

\subsection{Saran}

Merevisi aturan-aturan hukum nasional yang masih bercorak hukum penjajah, memang merupakan tantangan kemerdekaan yang dijawab generasi hari ini. Jika, pahlawan kemedekaan dulu berjuang dalam merebut kemerdekaan dari penjajah hingga "tetes darah" terakhir. Maka untuk konteks kekinian, menjadi kewajiban bagi para law maker untuk benar-benar mengakhiri segala bentuk dan tanda-tanda penjajahan yang dengan segala bentuk sistem hukumnya dengan menciptakan sistem hukum sendiri yang disesuaikan dengan jiwa bangsa Indonesia yang telah merdeka. Sebelum revisi tersebut dilakukan, Undang-Undang Darurat Nomor 1 Tahun 1951 tentang Tindakan-Tindakan Sementara untuk Menyelenggarakan Kesatuan Susunan Kekuasaan dan Acara PengadilanPengadilan Sipil dipakai untuk menjaga keseimbangan dan ketentraman dalam masyarakat, karena secara normatif ketentuan Pasal 284 KUHP tidak cukup representatif dalam mewakili rasa keadilan masyarakat dalam kaitannya dengan kasus-kasus perzinahan yang terjadi di tengah masyarakat.

\section{Daftar Pustaka}

Buku

Achmad Ali. (2002). Menyibak Tabir Hukum, Jakarta: Gunung Agung.

A. Suriyaman Mustari Pide (2017). Hukum Adat: Dahulu, Kini dan Akan Datang, Jakarta: Prenada Media Grup

Bambang Sunggono. (2003). Metodologi Penelitian Hukum, Cetakan Kelima, Jakarta Rajawali Pers, Jakarta.

Barda Nawawi Arief. (2009). RUU KUHP Sebuah Restrukturisasi/Rekonstruksi Sistem Hukum Pidana Indonesia, Semarang: Badan Penerbit Universitas Diponegoro,

Eman Sulaeman. (2008). Delik Perzinaan, Semarang: Walisongo Pers

I Gede Wiranata. (2006). Membedah Hukum Progresif, Jakarta: Kompas Media Nusantara

Soerjono Soekanto. (2013). Pokok-Pokok Sosiologi Hukum, PT. Raja Grafindo Persada. (2008). Faktor-Faktor yang Mempengaruhi Penegakan Hukum, Jakarta: PT. Raja Grafindo Persada Soerjono Soekanto. (1986). Pengantar Penelitian Hukum, Jakarta: Cetakan Ketiga, UI-Press.

Suparni Niniek. (2007). Eksistensi Pidana Denda dalam Sistem Pidana dan Pemidanaan, Jakarta: Sinar Grafika 
Jurnal

H. Mustaghfirin. (2011). Sistem Hukum Barat, Sistem Hukum Adat, dan Sistem Hukum Islam Menuju sebagai Sistem Hukum Nasional Sebuah Ide yang Harmoni, Jurnal Dinamika Hukum, Vol. 11 Edisi Khusus Februari 2011, Fakultas Hukum, Universitas Jenderal Soedirman.

Yoserwan. (2017). "Penerapan Fungsi Sekunder Hukum Pidana Oleh Aparatur Penegak Hukum Dalam Hukum Pidana Ekonomi." Jurnal Nagari Law Review. Volume 1 Nomor 1, Oktober 2017, Fakultas Hukum Universitas Andalas.

\section{Peraturan Perundang-Perundangan}

Undang-Undang Dasar Negara Republik Indonesia Tahun 1945.

Undang-Undang Dasar Sementara Republik Indonesia.

Konstitusi Republik Indonesia Serikat.

Kitab Undang-Undang Hukum Pidana.

Undang-Undang Nomor 6 Tahun 2014 tentang Desa (Lembaran Negara Republik Indonesia Tahun 2014 Nomor 7).

Undang-Undang Nomor 48 Tahun 2009 tentang Kekuasaan Kehakiman (Lembaran Negara Republik Indonesia Tahun 2009 Nomor 157).

Undang-Undang Nomor 27 Tahun 1999 tentang Perubahan Kitab Undang-Undang Hukum Pidana yang Berkaitan dengan Kejahatan Terhadap Keamanan Negara (Lembaran Negara Republik Indonesia Tahun 1999 Nomor 74).

Undang-Undang Nomor 4 Tahun 1976 tentang Perubahan dan Penambahan Beberapa Pasal dalam

Kitab Undang-Undang Hukum Pidana Bertalian dengan Perluasan Berlakunya Ketentuan Perundang-undangan Pidana, Kejahatan Penerbangan, dan Kejahatan Terhadap Sarana/Prasarana Penerbangan.

Undang-Undang Nomor 1 Tahun 1960 tentang Perubahan Kitab Undang-Undang Hukum Pidana.

Undang-Undang Nomor 5 Tahun 1960 tentang Peraturan Dasar Pokok-Pokok Agraria (Lembaran Negara Republik Indonesia Tahun 1960 Nomor 104).

Undang-Undang Nomor 73 Tahun 1958 tentang Menyatakan Berlakunya Undang-Undang No. 1 Tahun 1946 Republik Indonesia tentang Peraturan Hukum Pidana untuk Seluruh Wilayah Republik Indonesia dan Mengubah Undang-Undang Hukum Pidana (Lembaran Negara Republik Indonesia Tahun 1958 Nomor 127).

Undang-Undang Darurat Nomor 1 Tahun 1951 tentang Tindakan-Tindakan Sementara untuk Menyelenggarakan Kesatuan Susunan Kekuasaan dan Acara Pengadilan-Pengadilan Sipil. Undang-Undang Nomor 1 Tahun 1946 tentang Peraturan Hukum Pidana.

Peraturan Pemerintah Nomor 2 Tahun 1945 tentang Badan-Badan dan Peraturan Pemerintah Dulu. Putusan Mahkamah Konstitusi Republik Indonesia Nomor : 46/PUU-XIV/2016.

\section{Internet}

www.detik.com

www.eramuslim.com

www.kumparan.com

www.wahdah.or.id 